\title{
Expression of Stanniocalcin-1 as a Predictor of Recurrence in Breast Cancer Patients
}

\author{
Yan Wisnu Prajoko ${ }^{1 *}$, Rizka Hastari ${ }^{2}$, Muflihatul Muniroh $^{3}$ D, Dik Puspasari ${ }^{4}$ \\ ${ }^{1}$ Department of Surgical Oncology, Faculty of Medicine, Diponegoro University, Kariadi Hospital, Semarang, Indonesia; \\ ${ }^{2}$ Department of Biomedical Science, Faculty of Medicine, Diponegoro University, Semarang, Indonesia; ${ }^{3}$ Department of \\ Physiology, Faculty of Medicine, Diponegoro University, Semarang, Indonesia; ${ }^{4}$ Department of Anatomical Pathology, Faculty \\ of Medicine, Diponegoro University, Kariadi Hospital, Semarang, Indonesia
}

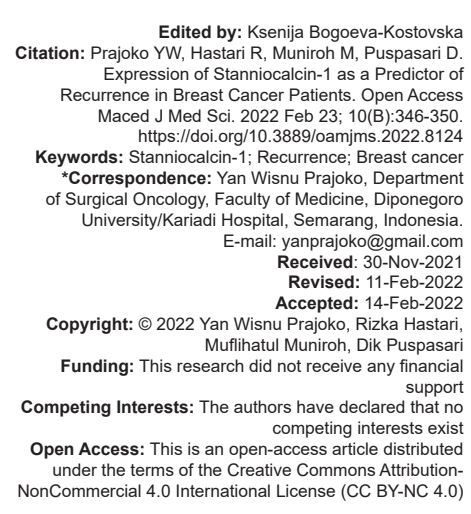

\section{Introduction}

Breast cancer is one of the most common types of cancer in women in the world. In 2018 there were around 2.89 million women diagnosed with breast cancer with a mortality rate of 627,000 people [1]. In Indonesia, in 2018 there were 59,256 women diagnosed with breast cancer, with the mortality rate reaches $12.75 \%$ [1], [2]. Breast cancer treatment is a multidisciplinary treatment that includes systemic therapy, local therapy, and supportive therapy. However, all of these efforts still have a risk of recurrence in the future, especially in patients with advanced stages [3], [4]. Approximately $40 \%$ of patients who have undergone a series of breast cancer therapy will experience a recurrence.

Recurrence of breast cancer will reduce the patient's life expectancy by up to $40 \%$ whereas patients who do not experience recurrence have a life expectancy of $95 \%$ [5], [6]. The risk of recurrence in breast cancer should be known early because in addition to affecting life expectancy, recurrence will also affect the patient's quality of life and increase hospital costs. Several factors that influence the recurrence of breast cancer include young age, tumor size, biomarker status of Human Epidermal Growth Factor Receptor 2 (HER-2), Estrogen Receptor (ER), negative Progesterone Receptor (PR), presence of lymph node involvement, high grade in anatomical pathology [6], [7], [8], [9].

One of the biomarkers that are thought to be a predictor of recurrence in breast cancer is Stanniocalcin-1 (STC1) [10], [11]. STC1 which is a protein excreted by several organs including the thyroid, ovaries, liver, prostate, and kidneys. STC1 is strongly expressed in breast cancer tissue and is not expressed in normal breasts [12]. STC1 has been investigated to play a role in cancer signaling in the P13K/Akt pathway which will affect the invasiveness of cancer cells [13]. Several studies have also shown that therapy with STC1 antibody can inhibit the aggressiveness of cancer cells in cases of triple-negative breast cancer (TNBC) in vitro.

Based on this, it is suspected that STC1 has the potential as a predictor of cancer. However, until now there has been no further research on this matter. 
Therefore, research is needed on the expression of STC1 as a risk factor for recurrence in breast cancer patients and to determine the relationship between STC1 expression on the incidence of recurrence in breast cancer patients.

\section{Methods}

This research is an observational study with a cross-sectional study method. The research sample was paraffin block from breast cancer patients who underwent surgery at Kariadi Hospital from January 2016 to December 2016. Anatomical pathology and immunohistochemistry examinations were carried out at the Anatomical Pathology Department of Faculty of Medicine Diponegoro University/Kariadi Hospital Semarang. Demographic data, staging, and biomarker status (Estrogen Receptor, Progesterone Receptor, and Human Epidermoid Receptor-2) were taken from the patient's medical records. Further confirmation of the patient's current condition through medical records and telephone.

The population of this study was invasive breast cancer patients in women with Stage I, II, and III who came and were treated at Kariadi Hospital Semarang Indonesia.

After the data is collected, then tabulation and coding are carried out. Statistical analysis was performed using SPSS version 25 software (SPSS, IBM). Analysis of the data regarding the relationship of STC1 with recurrence using the Chi-square test or Fisher's Exact test, then Logistic regression analysis was carried out to determine the relationship between significant risk factors for recurrence.

\section{Results}

This study involved fifty-two breast cancer patients who met the requirements for completeness of medical records and paraffin blocks were still available in the Anatomical Pathology Department of the Kariadi Hospital (Figure 1), fifty-two breast cancer patients were divided into two groups, namely the group with recurrence of thirty-two patients and the group without recurrence as many as twenty patients. Most of the patients who experienced recurrence were patients aged more than 46-years-old, the most character in tumor size was T3, lymph node status was N2 and N3, mostly stage III, most subtype was triple-negative, the most histopathological grade was intermediate and most STC1 scoring was >6.7 (Table 1). There was a significant relationship between ER, PR, and STC1

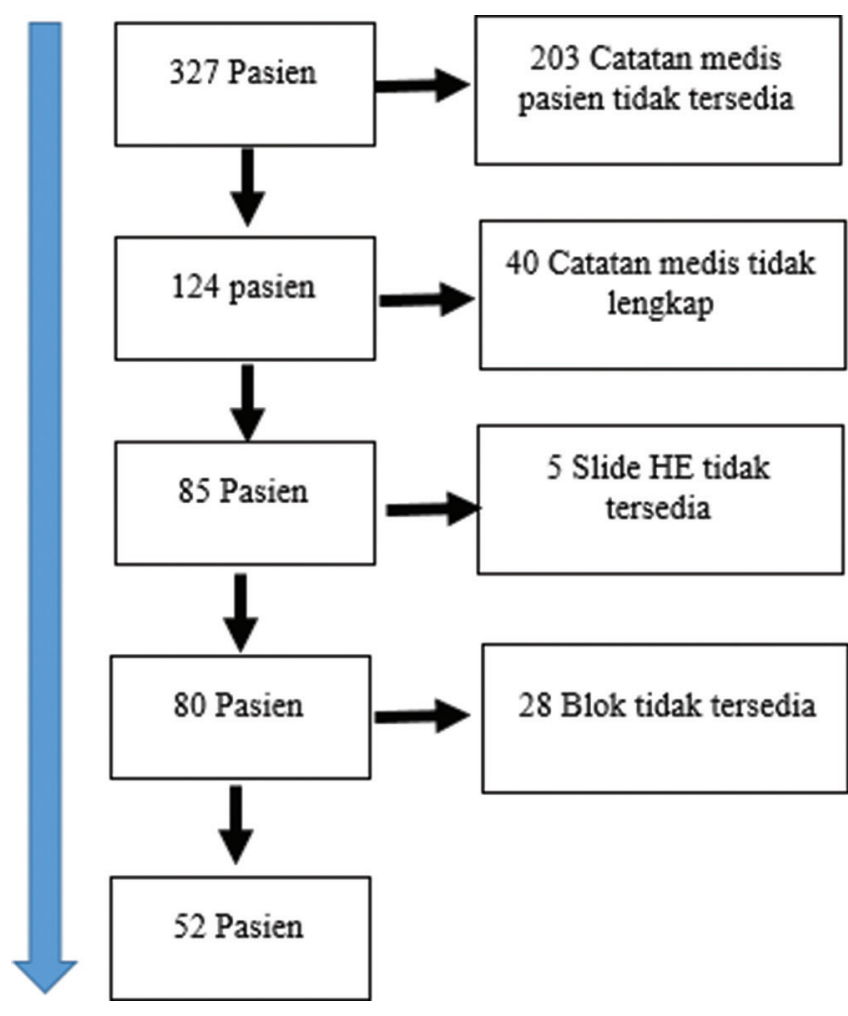

Figure 1: Flow of getting research sample

expression on recurrence and there was no significant relationship between HER-2 expression and recurrence in breast cancer patients (Table 2). There was a significant relationship between STC1 expression and cancer subtype (TNBC) and the patient's lymph node status (N3) (Table 3).

Table 1 shows that several risk factors for recurrence in breast cancer include age, tumor size, lymph node involvement, stage, tumor type (Luminal, HER-2, and TNBC), and STC1 expression. The results of statistical tests with Chi-Square found several risk factors that were significantly associated with recurrence, i.e., age more than 45-years-old, tumor size $>$ T2, with lymph node involvement, TNBC subtype, and strong STC1 expression.

Several significant risk factors in the ChiSquare test will then be tested with logistic regression, previously several risk factors were categorized into 2 categories such as stage, tumor size, nodule, and age. From the results of the logistic regression test, it was found that Crude OR was greater than Adjusted OR for STC1 expression $>6.7$, stage $>2$, age $>45$ and TNBC cancer type, while tumor size < T2, KGB N0 status, and ER status (+) has a smaller Crude OR than the Adjusted OR. This shows that recurrence is influenced by STC1 expression $>6.7$, stage $>2$, age $>45$ and type of TNBC cancer, while tumor size $<2$, N0 lymph node status and ER $(+)$ status are protective factors against recurrence (Table 4).

In IHC examination, STC1 is expressed on the cell membrane and cytoplasm which will appear brownish in color, as in Figure 2a according to Allred 
Table 1: Patient characteristics and recurrence

\begin{tabular}{|c|c|c|c|c|c|c|c|c|}
\hline \multirow[t]{2}{*}{ Characteristics } & \multicolumn{3}{|l|}{ Recurrency } & \multirow[t]{2}{*}{ No recurrencies } & \multirow[t]{2}{*}{$p$} & \multicolumn{2}{|c|}{ Current condition } & \multirow[t]{2}{*}{$p$} \\
\hline & Locoregional & Distant & Mixed & & & Dead & Alive & \\
\hline \multicolumn{9}{|l|}{ Age } \\
\hline$<45$ & $1(5.9)$ & $3(17.6)$ & $1(5.9)$ & $12(70.6)$ & \multirow{3}{*}{$0.003^{*}$} & $5(29.4)$ & $12(70.6)$ & \multirow{3}{*}{$0.014^{*}$} \\
\hline $46-59$ & $3(10)$ & $18(60)$ & $3(10)$ & $6(20)$ & & $22(73.3)$ & $8(26.7)$ & \\
\hline$\geq 60$ & $1(20)$ & $2(40)$ & $0(0)$ & $2(40)$ & & $3(60)$ & $2(40)$ & \\
\hline \multicolumn{9}{|l|}{ Tumor Size } \\
\hline T1 & $0(0)$ & $0(0)$ & $0(0)$ & $1(100)$ & \multirow[t]{4}{*}{$0.004^{*}$} & $0(0)$ & $1(100 \%)$ & \multirow[t]{4}{*}{$0.000^{*}$} \\
\hline T2 & $2(12.5)$ & $2(12.5)$ & $0(0)$ & $12(75)$ & & $3(18.8)$ & $13(81.3)$ & \\
\hline T3 & $1(5)$ & $11(55)$ & $1(5)$ & $7(35)$ & & $12(60)$ & $8(40)$ & \\
\hline T4 & $2(13.3)$ & $10(10)$ & $3(20)$ & $0(100)$ & & $15(100)$ & $0(0)$ & \\
\hline \multicolumn{9}{|l|}{ Node Status } \\
\hline No & $1(3.6)$ & $7(25)$ & $2(7.1)$ & $18(64.3)$ & \multirow[t]{4}{*}{$0.001^{*}$} & $10(35.7)$ & $18(64.3)$ & \multirow[t]{4}{*}{$0.006^{*}$} \\
\hline N1 & $2(25)$ & $9(69.2)$ & $0(0)$ & $2(15.4)$ & & 10 (76.9) & $3(23.1)$ & \\
\hline N2 & $2(25)$ & $5(62.5)$ & $1(12.5)$ & $0(0)$ & & $7(87.5)$ & $1(12.5)$ & \\
\hline N3 & $0(0)$ & $2(66.7)$ & $1(33.3)$ & $0(0)$ & & $3(100)$ & $0(0)$ & \\
\hline \multicolumn{9}{|l|}{ Stage } \\
\hline 1 & $0(0)$ & (0) & (0) & $1(100)$ & \multirow[t]{3}{*}{$0.001^{*}$} & $0(0)$ & $1(100)$ & \multirow[t]{3}{*}{$0.000^{*}$} \\
\hline II & $1(4.5)$ & $4(18.2)$ & $1(4.5)$ & $16(72.7)$ & & $6(27.3)$ & $16(72.7)$ & \\
\hline III & $4(13.8)$ & $19(65.5)$ & $3(10.3)$ & $3(10.3)$ & & $24(82.8)$ & $5(17.2)$ & \\
\hline \multicolumn{9}{|l|}{ Subtype } \\
\hline Luminal & $10(28.6)$ & $4(11.4)$ & $2(5.7)$ & 19 (54.3) & \multirow[t]{3}{*}{$0.015^{*}$} & $14(40)$ & $21(60)$ & \multirow[t]{3}{*}{$0.001^{*}$} \\
\hline HER-2 & $0(0)$ & $4(80)$ & $0(0)$ & $1(20)$ & & $4(80)$ & $1(20)$ & \\
\hline TNBC & $1(8.3)$ & $9(75)$ & $2(16.7)$ & $0(0)$ & & $12(100)$ & $0(0)$ & \\
\hline \multicolumn{9}{|c|}{ Histopatological grade } \\
\hline Grade II & $4(9.5)$ & $18(42.9)$ & $3(7.1)$ & $17(40.5)$ & \multirow[t]{2}{*}{$0.938^{*}$} & $23(54.8)$ & $19(45.2)$ & \multirow[t]{2}{*}{$0.305^{* *}$} \\
\hline Grade III & $1(10)$ & $5(50)$ & $1(10)$ & $3(30)$ & & $7(70)$ & $3(30)$ & \\
\hline \multicolumn{9}{|l|}{ STC-1 } \\
\hline Allred score $>6.7$ & $3(14.8)$ & $19(70.4)$ & $1(3.7)$ & $4(14.8)$ & \multirow[t]{2}{*}{$0.001^{* *}$} & $23(85.2)$ & $4(14.8)$ & \multirow[t]{2}{*}{$0.001^{* \star}$} \\
\hline Allred score $\leq 6.7$ & $1(4)$ & $4(16)$ & $3(12)$ & $18(72)$ & & $7(28)$ & $18(22)$ & \\
\hline
\end{tabular}

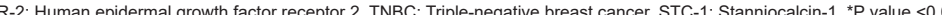

Table 2: Relationship between STC1, ER, PR, and HER-2 expression with recurrence

\begin{tabular}{|c|c|c|c|}
\hline Immunology profile & $\begin{array}{l}\text { Recurrence } \\
\mathrm{n}(\%)\end{array}$ & $\begin{array}{l}\text { No recurrence } \\
\mathrm{n}(\%)\end{array}$ & $p$ \\
\hline \multicolumn{4}{|l|}{$\overline{E R}$} \\
\hline $\operatorname{ER}(+)$ & $16(44.4)$ & $20(55.6)$ & \multirow[t]{2}{*}{$0.001^{* *}$} \\
\hline $\operatorname{ER}(-)$ & $16(100)$ & $0(0)$ & \\
\hline \multicolumn{4}{|l|}{ PR } \\
\hline PR (+) & $16(44.4)$ & $20(55.6)$ & \multirow[t]{2}{*}{$0.001^{* \star}$} \\
\hline PR $(-)$ & $16(100)$ & $0(0)$ & \\
\hline \multicolumn{4}{|l|}{ HER 2} \\
\hline HER $2(+)$ & $5(71.4)$ & $2(28.6)$ & \multirow[t]{2}{*}{$0.402^{* \star}$} \\
\hline HER $2(-)$ & $26(57.8)$ & $19(42.2)$ & \\
\hline \multicolumn{4}{|l|}{ STC-1 } \\
\hline Allred score $>6.7$ & $23(85.2)$ & $4(14.8)$ & \multirow{2}{*}{$0.001^{* *}$} \\
\hline Allred score $\leq 6.7$ & $7(28)$ & $18(72)$ & \\
\hline
\end{tabular}

Score $>6.7$ while in Figure $2 \mathrm{~b}$ and $\mathrm{c}$ with Allred Score $\leq 6.7$.

Table 3: Relationship of STC-1 expression and patient characteristics

\begin{tabular}{|c|c|c|c|}
\hline \multirow[t]{2}{*}{ Characteristics } & \multicolumn{3}{|l|}{ STC-1 } \\
\hline & $\begin{array}{l}\text { Allred score }>6.7 \\
\mathrm{n}(\%)\end{array}$ & $\begin{array}{l}\text { Allred score } \leq 6.7 \\
\mathrm{n}(\%)\end{array}$ & $p$ \\
\hline \multicolumn{4}{|l|}{ Age } \\
\hline$<45$ & $5(29.4)$ & $12(70.6)$ & \multirow{3}{*}{$0.055^{\star}$} \\
\hline $46-59$ & $18(60)$ & $12(40)$ & \\
\hline$\geq 60$ & $4(80)$ & $1(20)$ & \\
\hline \multicolumn{4}{|l|}{ Tumor Size } \\
\hline $\mathrm{T} 1$ & $0(0)$ & $1(100)$ & \multirow{4}{*}{$0.284^{*}$} \\
\hline $\mathrm{T} 2$ & $6(37.5)$ & $10(62.5)$ & \\
\hline T3 & $11(55)$ & $9(45)$ & \\
\hline $\mathrm{T} 4$ & $10(66.7)$ & $5(33.3)$ & \\
\hline \multicolumn{4}{|l|}{ Node Status } \\
\hline No & $10(35.7)$ & $18(64.3)$ & \multirow{3}{*}{$0.030^{*}$} \\
\hline N1 & $9(69.2)$ & $4(30.8)$ & \\
\hline N2 & $7(87.5)$ & $1(12.5)$ & \\
\hline N3 & $1(33.3)$ & $2(66.7)$ & \\
\hline \multicolumn{4}{|l|}{ Stage } \\
\hline 1 & $0(0)$ & $1(100)$ & \multirow{3}{*}{$0.069^{*}$} \\
\hline II & $8(36.4)$ & $14(63.6)$ & \\
\hline III & $19(65.5)$ & $10(34.5)$ & \\
\hline \multicolumn{4}{|l|}{ Subtypes } \\
\hline Luminal & $14(40)$ & $21(60)$ & \multirow{3}{*}{$0.047^{*}$} \\
\hline HER-2 & $4(80)$ & 1 (20) & \\
\hline TNBC & $9(75)$ & $3(25)$ & \\
\hline \multicolumn{4}{|c|}{ Histopathologic grades } \\
\hline Grade II & $21(50)$ & $21(50)$ & \multirow[t]{2}{*}{0.729} \\
\hline Grade III & $6(60)$ & $4(40)$ & \\
\hline
\end{tabular}

Discussion

STC1 is a protein that is an oncogene if the amount is excessive in the human body. Under normal conditions, STC1 will be expressed in several tissues such as the thyroid, ovary, liver, prostate, and kidney [14]. Expression of STC1 is associated with recurrence in breast cancer because of the nature of STC1 that can affect cancer cell growth, angiogenesis, and metastasis [11], [13], [15].

Table 4: Relationship of recurrence with breast cancer characteristics and expression of STC-1

\begin{tabular}{llllll}
\hline Risk factors & \multicolumn{2}{l}{ Recurrence } & Crude OR & Adjusted OR & $\mathbf{9 5 \%} \mathbf{C l}$ \\
\cline { 2 - 3 } & Yes & No & & & \\
\hline STC1 score>6.7 & 23 & 4 & 14.79 & 31.03 & $2.115-455.511$ \\
Tumor size<T2 & 25 & 9 & 7.22 & 0.49 & $0.19-12.559$ \\
Stage & 24 & 5 & 13.6 & 164.7 & $1.426-19037.7$ \\
ER Status $(+)$ & 14 & 2 & 8.75 & 0.93 & $0.003-3.017$ \\
Nodal Status N0 & 20 & 4 & 9.00 & 0.42 & $0.030-6.072$ \\
Age $>45$ & 25 & 11 & 0.2 & 0.40 & $0.032-4.797$ \\
TNBC & 11 & 1 & 12.15 & 294.1 & $1.840-47003.5$ \\
\hline STC-1: Stanniocalcin-1, ER: Estrogen receptor, TNBC: Triple-negative breast cancer. &
\end{tabular}

In this study, the majority of breast cancer patients were luminal types $(67.3 \%)$ this is in accordance with the data that most breast cancers in Indonesia are luminal types, which is around $41.3 \%$ both luminal A and luminal B.20 In this study as many as $30.8 \%$ of patients with luminal type $A$ had a recurrence in the first 2 years after the patient finished treatment, this exceeded the estimated recurrence in patients with luminal type, which was about $20 \%$. In this study, it was found that the type of TNBC cancer was the type that experienced the most recurrences compared to the others. in this study it was found that the type of TNBC cancer will express STC1 strongly, this is in accordance with research conducted by Brantley which states STC1 as a predictor of recurrence in TNBC subtype, as previously known that TNBC subtype is a cancer with worst prognosis amongst all types of breast cancer [10], [16], [17], [18]. 


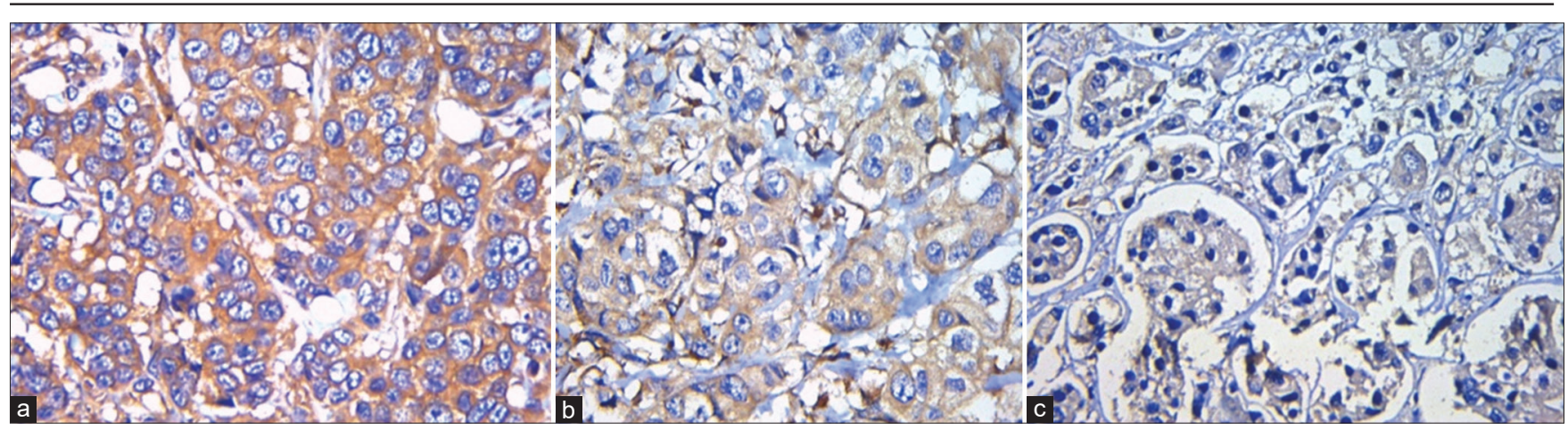

Figure 2: Microscopic expression of Stanniocalcin-1

In a previous study, it was found that patients with STC1 (+) will mostly experience locoregional recurrence at 3 years after completion of treatment, but in this study, most of them experienced distant recurrence, this is possible because the patients in the previous study were mostly diagnosed in stage I and II while the patients in this study were mostly diagnosed at stage II and III.

\section{Conclusion}

Recurrence in breast cancer can be detected with the expression of STC1, besides that patient characteristics are also closely related to recurrence, in this study patients with a strong expression of STC1, stage $>2$, age $>45$ years and the type of TNBC cancer are patients who are susceptible to recurrence. This study can be used as the basis for further research using STC1 as a therapeutic target to prevent breast cancer recurrence.

\section{Acknowledgment}

Thank you to RSUP Dr Kariadi Semarang and the PA Section of RSUP Dr. Kariadi who has helped the smooth running of this research.

\section{References}

1. Sung H, Ferlay J, Siegel RL, et al. Global Cancer Statistics 2020: GLOBOCAN Estimates of Incidence and Mortality Worldwide for 36 Cancers in 185 Countries. CA Cancer J Clin. 2021;71(3). doi:10.3322/caac. 21660

PMid: 33538338

2. Penyakit Kanker S. InfoDATIN 4 Februari-Hari Kanker Sedunia.; 2015.
3. $\mathrm{Ng} \mathrm{CH}$, Bhoo Pathy N, Taib NA, et al. Comparison of breast cancer in Indonesia and Malaysia - A clinico-pathological study between dharmais cancer centre Jakarta and university Malaya medical centre, Kuala Lumpur. Asian Pacific J Cancer Prev. 2011;12(11):2943-6

4. Colleoni $\mathrm{M}$, Sun $\mathrm{Z}$, Price $\mathrm{KN}$, et al. Annual hazard rates of recurrence for breast cancer during 24 years of follow-up: Results from the international breast cancer study group trials I to V. J Clin Oncol. 2016;34(9). doi:10.1200/JCO.2015.62.3504 PMid: 26786933

5. Montalvo DN, González NM, Montalvo MTV, Jiménez AA, Echiburú-Chau C, Calaf GM. Patterns of recurrence and survival in breast cancer. Oncol Rep. 2008;20(3).

6. Joensuu K, Leidenius M, Kero M, Andersson LC, Horwitz KB Heikkilä P. ER, PR, HER2, Ki-67 and CK5 in early and late relapsing breast cancer-reduced $\mathrm{CK} 5$ expression in metastases. Breast Cancer Basic Clin Res. 2013;7(1). doi:10.4137/BCBCR. S10701

PMid: 23514931

7. Song F, Zhang J, Li S, Wu J, Jin T, Qin J, et al. ER-positive breast cancer patients with more than three positive nodes or grade 3 tumors are at high risk of late recurrence after 5-year adjuvant endocrine therapy. Onco Targets Ther. 2017;10:4859-67. http://doi.org/10.2147/OTT.S142698 PMid:29042797

8. Kabel AM. Tumor Marker of Breast Cancer: New Prospective Journal of Oncological Sciences; 2017. p. 3.

9. van der Leij F, Elkhuizen PH, Bartelink H, van de Vijver MJ Predictive factors for local recurrence in breast cancer. Semin Radiat Oncol. 2012;22(2):100-7. http://doi.org/10.1016/j. semradonc.2011.12.001 PMid:22385917

10. Brantley KD, Kjærsgaard A, Cronin-Fenton D, Yacoub R, Nielsen AS, Lauridsen $\mathrm{KL}$, et al. Stanniocalcin expression as a predictor of late breast cancer recurrence. Cancer Epidemiol Biomarkers Prev. 2018;27(6):653-9. http://doi. org/10.1158/1055-9965.EPI-17-0905 PMid:29593009

11. Hou Y, Wang XZ, Hang YK, Liu JB, Wang MJ. High expression of STC1 is associated with poor prognosis of breast cancer patients. Int J Clin Exp Pathol. 2016;9:11826-31.

12. Wascher RA, Huynh KT, Giuliano AE, Hansen NM, Singer FR, Elashoff D, et al. Stanniocalcin-1: A novel molecular blood and bone marrow marker for human breast cancer. Clin Cancer Res. 2003;9(4):1427-35.

13. Jeon M, Han J, Nam SJ, Lee JE, Kim S. STC-1 expression is upregulated through an Akt/NF-kB-dependent pathway in triplenegative breast cancer cells. Oncol Rep. 2016;36(3):1717-22.

14. Fang Z, Tian Z, Luo K, Song $\mathrm{H}$, Yi J. Clinical significance of stanniocalcin expression in tissue and serum of gastric cancer patients. Chin J Cancer Res. 2014;26(5):602-10. http://doi. 
org/10.3978/j.issn.1000-9604.2014.10.08

PMid:25400427

15. Chang AC, Doherty J, Huschtscha LI, Redvers R, Restall C, Reddel RR, et al. STC1 expression is associated with tumor growth and metastasis in breast cancer. Clin Exp Metastasis. 2015;32(1):15-27. http://doi.org/10.1007/s10585-014-9687-9 PMid:25391215

16. Wickberg A, Magnuson A, Holmberg L, Adami HO, Liljegren G. Influence of the subtype on local recurrence risk of breast cancer with or without radiation therapy. Breast. 2018;42:54-60. http://doi.org/10.1016/j.breast.2018.08.097

PMid:30176553

17. Senkus E, Kyriakides S, Ohno S, et al. Primary breast cancer: ESMO Clinical Practice Guidelines for diagnosis, treatment and follow-up. Ann Oncol. 2015;26. doi:10.1093/annonc/mdv298 PMid: 26314782

18. Rosa Mendoza ES, Moreno E, Caguioa PB. Predictors of early distant metastasis in women with breast cancer. J Cancer Res Clin Oncol. 2013;139(4). doi:10.1007/s00432-012-1367-z

PMid: 23283528 